\title{
Karyotypes of four species of the genus Telenomus Haliday, 1833 (Hymenoptera: Scelionidae)
}

\author{
Кариотипы четырех видов рода Telenomus Haliday, 1833 \\ (Hymenoptera: Scelionidae)
}

\author{
V.E. Gokhman ${ }^{1}$, A.V. Timokhov ${ }^{2}$ \\ B.E. Гохман ${ }^{1}$, A.B. Тимохов ${ }^{2}$
}

\footnotetext{
${ }^{1}$ Botanical Garden, Moscow State University, Moscow 119234, Russia. E-mail: vegokhman@hotmail.com

2 Department of Entomology, Moscow State University, Moscow 119234, Russia. E-mail: atimokhov@mail.ru

${ }^{1}$ Ботанический сад Московского государственного университета, Москва 119234, Россия.

2 Кафедра энтомологии Московского государственного университета, Москва 119234, Россия.
}

KEY WORDS. Telenominae, karyotype, chromosome morphometrics.

КЛЮЧЕВЫЕ СЛОВА. Telenominae, кариотип, морфометрия хромосом.

ABSTRACT. Karyotypes of four species of the genus Telenomus Haliday, 1833, namely, T. acrobates Giard, 1895, T. angustatus (Thomson, 1861), T. heydeni Mayr, 1879 and T. turesis Walker, 1836 were studied for the first time using chromosome morphometrics. Although all examined members of the genus appeared to have $\mathrm{n}=10$, substantial differences between karyotypes of certain species were revealed.

РЕЗЮМЕ. С использованием морфометрии хромосом впервые изучены кариотипы четырёх видов рода Telenomus Haliday, 1833, а именно, T. acrobates Giard, 1895, T. angustatus (Thomson, 1861), T. heydeni Mayr, 1879 и T. turesis Walker, 1836. Хотя у всех исследованных представителей рода обнаружено $\mathrm{n}$ $=10$, выявлены существенные различия между кариотипами некоторых видов.

\section{Introduction}

Parasitoid Hymenoptera is one of the most speciose, taxonomically complicated and economically important insect groups, with its estimated species number in the world fauna far exceeding one million [Quicke, 1997; Bebber et al., 2014; Forbes et al., 2018]. Despite rapid accumulation of karyotypic data, they are still available for just about 500 species of parasitic wasps [Gokhman, 2009]. The parasitoid superfamily Platygastroidea, which currently comprises about 6000 described species [Timokhov, 2019], is traditionally subdivided into two separate families, Platygastridae and Scelionidae. In turn, the latter group contains more than
4000 species in the world fauna [Timokhov, 2019]. Among the Scelionidae, karyotypes of six members of the subfamily Telenominae that belong to the genera Trissolcus Ashmead, 1893 and Telenomus Haliday, 1833 were previously studied (see Gokhman, Timokhov, [2019] for review). Although all examined species appeared to have the same haploid chromosome number, $n$ $=10$, at least some members of the family can differ in certain details of their karyotype structure [Gokhman, Timokhov, 2019]. Moreover, for both studied Telenomus species, either the chromosome number remains the only known karyotypic feature, as in T. turesis Walker, 1836 [= chloropus (Thomson, 1861)] [Gokhman, 2009], or the existing description of the chromosome set contains apparent errors, e.g. presence of the putative "sex chromosomes", as in T. fariai Costa Lima, 1927 [Dreyfus, Breuer, 1944]. Using chromosome morphometrics, we have recently studied karyotypes of four members of the genus Telenomus including T. turesis. The results of this work are given below.

\section{Material and methods}

\section{Origin of parasitoids}

Parasitic wasps used in the present study were reared from host egg clutches or collected by sweeping in their natural habitats in the Moscow Province (Russia) in 2016-2019 (Table 1). Specifically, individuals of Telenomus acrobates Giard, 1895 and T. turesis were reared from eggs of an unidentified lacewing (Neuroptera: Chrysopidae) and Palomena prasina (Linnaeus, 1761) (Hemiptera: Pentatomidae) respectively, whereas adult

How to cite this article: Gokhman V.E., Timokhov A.V. 2020. Karyotypes of four species of the genus Telenomus Haliday, 1833 (Hymenoptera: Scelionidae) // Russian Entomol. J. Vol.29. No.2. P.214-217. doi: 10.15298/rusentj.29.2.17 
Table 1. Species of the genus Telenomus used in the present study Таблица 1. Виды рода Telenomus, использованные в настоящей работе

\begin{tabular}{|l|l|c|c}
\hline \multicolumn{1}{|c|}{ Species } & \multicolumn{1}{|c|}{ Locality } & $\begin{array}{c}\text { No. studied } \\
\text { specimens }\end{array}$ & $\begin{array}{c}\text { No. studied (haploid) and } \\
\text { diploid metaphase plates }\end{array}$ \\
\hline $\begin{array}{l}\text { T. acrobates } \\
\text { Giard, 1895 }\end{array}$ & $\begin{array}{l}\text { Zvenigorod Biological Station, Moscow } \\
\text { State University, about 55 km W Moscow }\end{array}$ & 1 & (3) \\
\hline $\begin{array}{l}\text { T. angustatus } \\
\text { Thomson, 1861) }\end{array}$ & $\begin{array}{l}\text { Prioksko-Terrasny Natural Reserve, about } \\
100 \text { km S Moscow }\end{array}$ & 2 & 4 \\
\hline $\begin{array}{l}\text { T. heydeni } \\
\text { Mayr, } 1879\end{array}$ & Prioksko-Terrasny Natural Reserve & 4 & (7) 9 \\
\hline $\begin{array}{l}\text { T. turesis } \\
\text { Walker, } 1836\end{array}$ & Prioksko-Terrasny Natural Reserve & 3 & 5 \\
\hline
\end{tabular}

specimens of $T$. heydeni were collected in the wild. Females of most parasitoid species were then transferred to egg clutches of lab hosts for oviposition, i.e. Chrysoperla carnea (Stephens, 1836) (Neuroptera: Chrysopidae) (for T. acrobates) and Graphosoma lineatum Linnaeus, 1758 (Hemiptera: Pentatomidae) (for both $T$. heydeni and $T$. turesis). To obtain wasp prepupae, parasitized host eggs were incubated in lab conditions for a few days. An ovipositing female of T. angustatus was observed on a single egg clutch of $\mathrm{Ta}$ banus sp. (Diptera: Tabanidae) in the field, and this clutch was taken to the lab and then used both for rearing adult wasps and obtaining immature stages for the cytogenetic study. All examined parasitoid species were identified by A.V. Timokhov. Voucher adult specimens of parasitic wasps are deposited in the collection of the Department of Entomology of Moscow State University (Moscow, Russia), except for several individuals of T. heydeni additionally deposited in the Florida State Collection of Arthropods (Gainesville, Florida, USA).

\section{Preparation of chromosomes}

Chromosome preparations were made from cerebral ganglia of parasitoid prepupae using a modified version of the technique described by Imai et al. [1988]. Wasps were dissected in $0.5 \%$ hypotonic sodium citrate solution containing $0.005 \%$ colchicine, and the tissues were incubated in fresh solution for 30 minutes at room temperature. The material was transferred to a precleaned microscope slide using a Pasteur pipette and gently flushed with Fixative I (glacial acetic acid: absolute ethanol: distilled water 3:3:4). Tissues were disrupted in an additional drop of Fixative I using dissecting needles. Another drop of Fixative II (glacial acetic acid: absolute ethanol 1:1) was then applied to the center of the area and blotted off the edges of the slide. The slide was air dried at room temperature. Preparations were stained with freshly prepared 3\% Giemsa solution in $0.05 \mathrm{M}$ Sorensen's phosphate buffer $\left(\mathrm{Na}_{2} \mathrm{HPO}_{4}+\mathrm{KH}_{2} \mathrm{PO}_{4}\right.$, $\mathrm{pH}$ 6.8).

\section{Image acquisition and analysis}

Mitotic divisions were studied and photographed using an optic microscope Zeiss Axioskop 40 FL fitted with a digital camera Axiocam 208 color (Carl Zeiss, Oberkochen, Germany). To obtain karyograms, the re- sulting images were handled with image processing programs ZEN version 3.1 (blue edition) and GIMP version 2.10. Chromosomes from selected metaphase plates were measured using KaryoType software version 2.0 (Table 2). Since centromere positions could not be reliably identified for many chromosomes, only relative lengths of chromosomes (RLs) are given in the present paper. Nevertheless, certain chromosomes from selected metaphase plates were classified using criteria listed by Levan et al. [1964].

\section{Results and discussion}

Telenomus acrobates (Fig. 1). $\mathrm{n}=10$. Chromosomes more or less gradually decrease in size, but the first element of the karyotype is visibly longer than the remaining ones. At least some chromosomes, including the first one, are clearly bi-armed.

T. angustatus (Fig. 2). $2 \mathrm{n}=20$. The first pair of chromosomes is more than twice longer than the others,

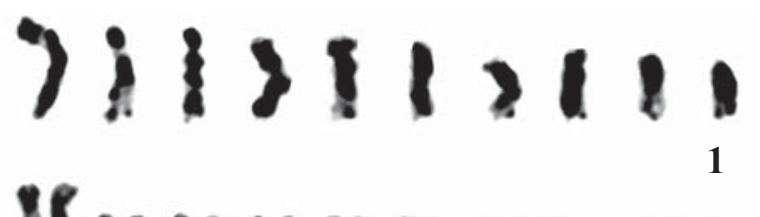

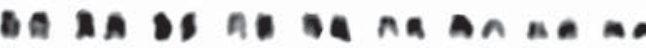

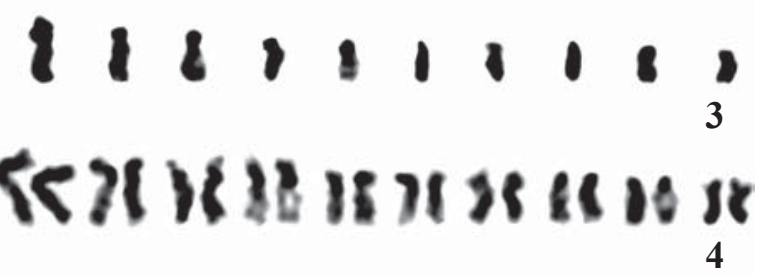

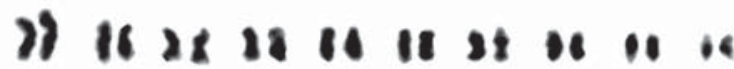

Figs 1-5. Karyograms of Telenomus species: $1-T$. acrobates, haploid set, $2-T$. angustatus, diploid set, $3-T$. heydeni, haploid set, 4 - ditto, diploid set, $5-T$. turesis, diploid set. Bar $-5 \mu \mathrm{m}$.

Рис. 1-5. Кариограммы видов Telenomus: $1-$ T. acrobates, гаплоидный набор, 2 - T. angustatus, диплоидный набор, 3 T. heydeni, гаплоидный набор, 4 - то же, диплоидный набор, 5 - T. turesis, диплоидный набор. Масштаб - 5 мкм. 
Table 2. Relative lengths of chromosomes of four species of the genus Telenomus (mean \pm SD) Таблица 2. Относительная длина хромосом четырёх видов рода Telenomus (среднее значение \pm стандартное отклонение)

\begin{tabular}{|c|r|r|r|r}
\hline $\begin{array}{c}\text { Chromosome } \\
\text { no. }\end{array}$ & T. acrobates & T. angustatus & T. heydeni & T. turesis \\
\hline 1 & $15.21 \pm 1.49$ & $23.24 \pm 1.03$ & $15.59 \pm 0.91$ & $14.07 \pm 0.59$ \\
\hline 2 & $12.52 \pm 0.33$ & $10.28 \pm 0.44$ & $12.27 \pm 0.63$ & $11.98 \pm 0.69$ \\
\hline 3 & $11.42 \pm 0.49$ & $9.84 \pm 0.15$ & $11.00 \pm 0.67$ & $11.41 \pm 0.59$ \\
\hline 4 & $11.05 \pm 0.60$ & $9.51 \pm 0.18$ & $10.13 \pm 0.33$ & $10.22 \pm 0.45$ \\
\hline 5 & $10.19 \pm 1.05$ & $9.20 \pm 0.29$ & $9.53 \pm 0.33$ & $9.80 \pm 0.02$ \\
\hline 6 & $9.63 \pm 1.27$ & $8.76 \pm 0.25$ & $9.04 \pm 0.21$ & $9.64 \pm 0.22$ \\
\hline 7 & $8.88 \pm 0.41$ & $8.07 \pm 0.06$ & $8.77 \pm 0.23$ & $9.28 \pm 0.11$ \\
\hline 8 & $8.30 \pm 0.17$ & $7.65 \pm 0.11$ & $8.41 \pm 0.28$ & $8.83 \pm 0.25$ \\
\hline 9 & $7.12 \pm 1.53$ & $6.95 \pm 0.21$ & $8.00 \pm 0.44$ & $7.75 \pm 0.31$ \\
\hline 10 & $5.68 \pm 0.93$ & $6.50 \pm 0.25$ & $7.26 \pm 0.73$ & $7.02 \pm 0.96$ \\
\hline
\end{tabular}

which form a continuous gradation in size. Moreover, the largest chromosome pair is obviously bi-armed (metacentric/submetacentric), whereas the remaining ones are either subtelocentric or acrocentric.

T. heydeni (Figs 3-4). $\mathrm{n}=10$ and $2 \mathrm{n}=20$. As in $T$. acrobates, chromosomes more or less gradually decrease in size. The first chromosome is slightly longer than the remaining elements. Again, at least some chromosomes (e.g. the first one) are clearly bi-armed.

T. turesis (Fig. 5). $2 \mathrm{n}=20$. The karyotype of this species is generally similar to those of $T$. acrobates and T. heydeni.

Nowadays, chromosomes of five Telenomus species are known, and this work therefore represents the first comparative karyotypic study of the genus. Our research confirms that all members of the genus Telenom$u s$, together with other Scelionidae, have the same chromosome number, $\mathrm{n}=10$ [Dreyfus, Breuer, 1944; Gokhman, 2009; Fusu et al., 2013; Gokhman, Timokhov, 2019]. Nevertheless, certain Telenomus species can differ in some details of their karyotype structure. For example, chromosomes of most members of this genus, as well as of other Scelionidae studied in this respect, more or less gradually decrease in size, except for $T$. angustatus, in which the first chromosome is more than twice longer than the remaining ones (Table 2). The latter member of the genus belongs to a separate species group, tabanivorus, whereas both T. turesis (formerly T. chloropus) and T. heydeni are currently placed into the podisi group [Johnson, 1984]. On the other hand, Telenomus species that develop inside neuropteran eggs, including $T$. acrobates, belong to the enormous and quite heterogeneous californicus species complex [Johnson, Bin, 1982] which is apparently related to the podisi group [Taekul et al., 2014]. Nevertheless, the karyotype structure is generally similar in all these species except $T$. angustatus.

Although a detailed phylogenetic study has not yet been performed for most members of the genus Telenomus, a preliminary analysis suggests that less advanced Telenomus species mainly attack true bugs (Hemiptera: Heteroptera) [Taekul et al., 2014]. If this is true, then the karyotype structure found in T. heydeni and T. turesis, as well as in T. acrobates, may represent the plesiomorphous character state, and that characteristic of $T$. angustatus is thus apomorphous. The present work therefore demonstrates that closely related species of the genus Telenomus and of the family Scelionidae in general can have substantially different chromosome sets, and we believe that further karyotypic research will confirm this assumption.

Acknowledgements. The present study is partly supported by a research grant from the Russian Foundation for Basic Research no. 18-04-00611. The work of AVT was carried out within the framework of the Russian State Research Project no. AAAA-A16-116021660101-5.

\section{References}

Bebber D.P., Polaszek A., Wood J.R.I., Barker C., Scotland R.W. 2014. Taxonomic capacity and author inflation // New Phytologist. Vol.202. P.741-742. doi: 10.1111/nph.12745.

Dreyfus A., Breuer M.E. 1944. Chromosomes and sex determination in the parasitic hymenopteron Telenomus fariai (Lima) // Genetics. Vol.29. P.75-82.

Forbes A.A., Bagley R.K., Beer M.A., Hippee A.C., Widmayer H.A. 2018. Quantifying the unquantifiable: Why Hymenoptera, not Coleoptera, is the most speciose animal order // BMC Ecology. Vol.18. Paper 21. doi: 10.1186/s12898-018-0176-x.

Fusu L., Bin F., Popovici O.A. 2013. First report of chromosomes of the parasitoid wasp Trissolcus basalis (Wollaston) (Hymenoptera: Platygastridae: Telenominae)// Entomological Science. Vol.16. P.263-265. doi: 10.1111/ens.12011.

Gokhman V.E. 2009. Karyotypes of parasitic Hymenoptera. Dordrecht: Springer. XIII + 183p p. doi: 10.1007/978-1-40209807-9.

Gokhman V.E., Timokhov A.V. 2019. Karyotypes of three species of the genus Trissolcus Ashmead, 1893 (Hymenoptera: Scelionidae) // Russian Entomological Journal. Vol.28. No.1. P.69-71.

Imai H.T., Taylor R.W., Crosland M.W.J., Crozier R.H. 1988. Modes of spontaneous chromosomal mutation and karyotype evolution in ants with reference to the minimum interaction hypothesis // Japanese Journal of Genetics. Vol.63. P.159-185. doi: $10.1266 /$ jjg.63.159.

Johnson N.F. 1984. Systematics of Nearctic Telenomus: classification and revisions of the podisi and phymatae species groups (Hymenoptera: Scelionidae) // Bulletin of the Ohio Biological Survey. New Series. Vol.6. No.3. P.1-113. 
Johnson N.F., Bin F. 1982. Species of Telenomus (Hym., Scelionidae), parasitoids of stalked eggs of Neuroptera (Chrysopidae and Berothidae) // Redia. Vol.65. P.189-206.

Levan A., Fredga K., Sandberg A.A. 1964. Nomenclature for centromeric position on chromosomes // Hereditas. Vol.52. P.201220. doi: 10.1111/j.1601-5223.1964.tb01953.x.

Quicke D.L.J. 1997. Parasitic wasps. London: Chapman \& Hall. XVII $+470 \mathrm{pp}$.

Taekul C., Valerio A.A., Austin A.D., Klompen H., Johnson N.F. 2014. Molecular phylogeny of telenomine egg parasitoids (Hy- menoptera: Platygastridae s.l.: Telenominae): evolution of host shifts and implications for classification // Systematic Entomology. Vol.39. P.24-35. doi: 10.1111/syen.12032.

Timokhov A.V. 2019. Superfamily Platygastroidea // Belokobylskij S.A., Samartsev K.G., Il'inskaya A.S. (eds.). Annotated catalogue of the Hymenoptera of Russia. Vol.2. Apocrita: Parasitica. Proceedings of the Zoological Institute Russian Academy of Sciences. Suppl.8. St Petersburg: Zoological Institute RAS. P.42-57. 